\title{
The South African national school curriculum: Implications for collaboration between teachers and speech-language therapists working in schools
}

\author{
Anna-Marie Wium, Sefako Makgatho Health Sciences University. * \\ Brenda Louw, East Tennessee State University.
}

\begin{abstract}
This critical review addresses the implications of the Curriculum and Assessment Plan Statement (CAPS) for collaboration between teachers and speech-language therapists (SLTs) in schools. A historical perspective on changes in the roles and responsibilities of SLTs is provided, reflecting a shift from supporting the child to supporting the teacher. Based on the role of SLTs and audiologists in schools, an innovative approach to the support of teachers is conceptualized. The curriculum content and methods support learners who experience challenges and barriers to learning in main stream classrooms. The implementation of the curriculum necessitates close collaboration between teachers and SLTS in order to ensure the best possible outcomes for all learners. This collaboration is reviewed by identifying the benefits of, and barriers to, the process, as well as crucial areas of collaboration. Inclusive education is mandated by White Paper 6 , and collaborative support of teachers by SLTs is presented from the learners' perspective within the context of the curriculum. An example of teacher support through the response to intervention (RTI) approach is described.
\end{abstract}

Keywords: South African school curriculum, collaboration, inclusive education, teachers, speech-language therapists

*Email address: anna-marie.wium@smu.ac.za.

South African Journal of Childhood Education | 2015 5(1): 19-41 | ISSN: 2223-7674 |๑ UJ
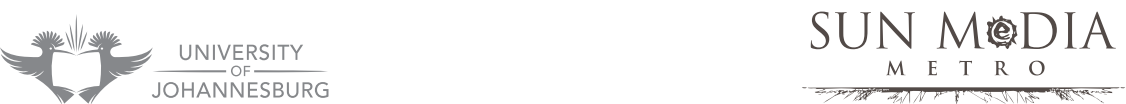


\section{Introduction}

The broad aim of the national Department of Basic Education's (DBE) Curriculum and Assessment Plan Statement (CAPS) is to develop, maintain and support a South African school education system for the 21st century (RSA DBE 2010a). The vision of the DBE is that all learners should be able to learn, and that inclusivity should therefore become a central part of the organization, planning and teaching at all schools in the country (RSA DBE 2010b; RSA DoE 2002). CAPS envisions closing the divide between learners in poor schools and their well-resourced counterparts, and identifying and addresssing the various barriers or challenges to learning. In terms of the CAPS document, which is based on inclusive education policies, learners who experience challenges and barriers to learning must receive the necessary support to enable them to learn in mainstream classrooms (RSA DoE 2001a; RSA DoE 2001b).

Speech-language therapists (SLTs) and audiologists have a long history of providing services to learners within the school context. However, this role has changed over the years. White Paper 6 (RSA DoE 2001b) and CAPS (RSA DBE 2010a) have led to a shift from supporting individual children to supporting all learners as well as teachers.

Given the changing educational landscape in South Africa, the question that arises is: how can teachers and SLTs collaborate to ensure the best educational outcomes for learners? The purpose of this article is to provide a critical review of the role of SLTs in schools and their collaboration with teachers, and to propose innovative ways for teachers and SLTs to collaborate within the CAPS framework. A historical overview of the changing role of SLTs in schools provides a backdrop for understanding their current role. The historical perspective is presented by contrasting the service provision by SLTs in the pre- and post-apartheid eras.

\section{Background: Historical perspective}

\section{Speech-language therapy and audiology services prior to 1994}

South Africa withdrew from the Commonwealth in 1961, and was under National Party rule until 1994. This period was characterized by an ideology of racial segregation and racial inequality, which was especially evident in educational service provision. Apart from a racially segregated education system, there were two separate education systems for mainstream and special education, also characterized by racial disparity. This resulted in a fragmented education system, with large numbers of learners being excluded from mainstream education (Naicker 2000). In addition, the fragmented and inequitable education system adversely affected the professional training of many teachers.

During this period, speech-language therapists and audiologists (SLTAs) were employed by either the provincial departments of education, under the auspices of the School Psychological Services, or in special schools. Such services were however mainly available to white children, and therefore the majority of the school-going population was at a disadvantage. At that time, speech and language therapy professionals were dually qualified as both speech-language therapists and 
audiologists, and were required to provide services in both disciplines. In mainstream as well as special education, the traditional role of these professionals was to identify learners who presented with speech, language, and hearing problems and provide the relevant therapy to treat them, or to refer them for further assessment and testing (Kathard, Jordaan, Moonsamy et al 2011).

Prior to 1994, the services provided by SLTAs were based on a deficit approach, according to which individual learners were supported because they had a speech/ hearing problem. Learners were taken out of their classrooms (individually or in small groups) to receive therapy in a separate room assigned for use by staff from School Psychological Services (which often implied the staff room, a store room, or a dressing room behind the stage in the school hall). Therapists, who were employed by one of the then four provincial departments of education, were required to visit schools on a weekly basis. Their caseloads consisted mainly of learners experiencing speech and language problems, for example, articulation, language delays, dysfluency, learning and reading problems (dyslexia), and, occasionally, voice and resonance problems due to a cleft lip or palate. They also performed hearing screening and referred learners who were considered to be at risk for further testing at government hospitals, university clinics or audiology practices (Kathard et al 2011).

Although children with learning problems were referred to the visiting speech therapist, those who required support in language acquisition related to multilingualism did not become a priority until the early 1990 s, when these issues were addressed in the international arena of speech-language pathology. The subject field of emergent literacy (including phonological awareness) also started developing during the 1990s (Van Kleeck, Gillam \& McFadden 1998). Prevention as a role and responsibility of the SLTA was only emerging, and there were no prevention approaches for learning problems due to currently known risk factors (for example, illiterate parents, unemployment, poverty, HIV/AIDS, etcetera).

Learners with specific disabilities were placed in special schools, which were also segregated. Special schools for white children provided a wide range of therapies to meet individual pupils' needs. Under the governing system of the time, learners in schools for so-called 'Coloured', Indian and African children did not receive similar support and mostly had to rely on their teachers, who were not adequately trained to assume this responsibility (Ratshitanga 2007).

\section{Speech-language therapy and audiology services since 1994}

Under the new political dispensation that came into being in 1994, the national Department of Education declared that "all learners (ages 0-9) should be provided with life skills and communication skills" (RSA DoE 1995:3). Children and youth with learning disabilities were to be supported in full-service schools, where they would be integrated with typically developing learners but have access to the support they need, provided to them at school. A small minority of severe cases requiring more intense and specialised support would be placed in special schools (RSA DoE 2008). 
Notwithstanding the above provisions, Education White Paper 6 on Special Needs Education: Building an Inclusive Education and Training System, which was launched in 2001 (RSA DoE 2001a), acknowledges that all learners need support. As the task of supporting each learner to learn falls to teachers, teachers themselves also require support. The CAPS documents, based on White Paper 5 (RSA DoE 2001a:Section 1.1.1) and White Paper 6 (RSA DoE 2001a:Section 1.1.5), requires a shift from previous models of supporting only the individual child (from the perspective of a deficit model) to supporting the teacher in order to prevent and eliminate learning problems in all learners. White Paper 6 stipulates that such support should include the provision of training, mentoring, monitoring, and consultation. Such education policies necessitated expanding the role of the SLT working in the educational environment to include teacher support.

Another change that has impacted the role of the speech-language therapist/ audiologist (SLTA) in schools is that, since the early 2000s, dual training programmes have been phased out and professionals now qualify as either SLTs or audiologists. Educational audiology is currently being emphasized in audiology programmes, and will become increasingly relevant in inclusive settings (EAA 2009), partly because of current (neuroscience) research that demonstrates the crucial role of phonology in learning to read (Yoncheva, Wise \& McCandliss 2015).

\section{The professional roles of the school-based SLT and audiologist}

Given the separate training programmes of SLTs and audiologists in South Africa, the respective roles of these professionals will be discussed separately.

\section{The role of SLTs in schools}

The responsibilities of SLTs in schools are varied (Paul \& Norbury 2012) and include the entire spectrum of professional tasks that are required by the American Speech and Hearing Association (ASHA 2010). It is therefore necessary to differentiate between SLTs' critical roles, the range of their responsibilities, collaboration and leadership. The critical roles require SLTs to work across all grade levels in schools (Grade $R$ to Grade 12) and address a range of disorders, including, for example, language, articulation, fluency, voice/resonance and swallowing disorders). These disorders may also require the SLT to provide counselling and educational services to families, caregivers, and others (ibid).

SLTs' expertise is further required for children and youth with cognitive communication disorders, as well as for individuals with limited or no verbal communication who require augmentative and alternative communication systems (AAC). SLTs have to ensure educational relevance by addressing personal, social/emotional, academic, and vocational needs that could affect academic performance. As part of a multidisciplinary team that supports learners, SLTs can contribute to the curriculum by supporting learners (particularly those who experience barriers to learning) to acquire linguistic and metalinguistic skills as foundation for learning (ASHA 2010). 
The traditional responsibilities of SLTs include:

- Prevention: The primary focus of SLTs working in schools is to prevent speech, hearing and communication disorders. Prevention is particularly important, as communication is central to the social, emotional and academic development of young children (Owens 2002). Considering SLTs knowledge of language, emergent literacy and phonology, prevention is best provided in the preschool and foundation phase, with suitable intervention for literacy development. SLTs contribute to the prevention of academic failure by employing evidence-based practice. Prevention not only requires SLTs to support all learners in literacy, which is of particular importance in the foundation phase, but to collaborate with teachers as well.

- Assessment: SLTs screen, identify and assess learners with language, learning and communication problems in collaboration with other professionals (for example, teachers, occupational therapists, physiotherapists, psychologists and remedial specialists) and parents. It is important that they distinguish between a language disorder and language difference, which requires recognition that some learners come from disadvantaged backgrounds and/or had inadequate prior instruction (RSA DoE 1997; RSA DoE 2002). Referrals for special education should be based on multiple assessment results.

- Intervention: The supportive role of the SLT in the school context entails support to both learners and teachers (ASHA 2010).. SLTs have to manage speech and communication problems (including learning problems) and provide culturally competent services based on their specialised knowledge of and skills in language acquisition. Intervention should be provided in accordance with the age and particular needs of learners, and should be culturally relevant (ASHA 2010). Learners with more severe disabilities may require individual attention that is more clinical in nature (for example, learners with dysphagia or those functioning on the autism spectrum).

- Data collection: Intervention requires that SLTs engage in effective data collection and analyses practices in order to design suitable programmes for individual as well as all other learners (RSA DBE 2012).

- Programme design: SLTs need to launch school-wide programmes that use a continuum of service delivery models that relate to all learners, including those with disabilities (ASHA 2010). Such programmes may range from whole-class teaching (for example, team teaching) to facilitate the development of language skills in all learners, to providing individual support for learners who require more intensive intervention (for example, learners with dysphagia).

- Compliance: The education environment requires SLTs to comply with government policies (for example, national and provincial regulations) as well as guidelines compiled by the HPCSA (2005). 
- Collaboration: In addition to providing direct services to learners with speech and oral language difficulties, SLTs are expected to support teachers and learners in the acquisition of literacy skills in order to prevent academic failure. SLTs are required to create supportive language contexts and to promote language learning in the classroom (Jordaan 2011). In older learners, SLTs can address reading and writing skills (Paul \& Norbury 2012). SLTs should also extend their support to primary caregivers or parents (RSA DBE 2012). Support programmes can provide parents with information about literacy and language acquisition and how they can be involved in the process.

It is clear that the SLT is an important member of the educational support team, especially when considering the philosophy of inclusive education, as contained in the national curriculum.

\section{The role of educational audiologists in schools}

Educational audiology has developed as an important field within audiology. In inclusive education settings, educational audiologists are responsible for i) administering assessment with regard to conservation of hearing; ii) screening for and identifying, assessing and preventing hearing loss; iii) cerumen management; and iv) rehabilitating learners with peripheral and central auditory system dysfunction (HPCSA 2005). Audiologists attend to aural (re)habilitation and counselling of children with hearing impairments and the counselling of their families as well. They are responsible for the selection, fitting, verification and dispensing of assistive listening devices (including frequency modulated systems). Their prime objectives are to create optimum listening environments and develop hearing conservation programmes. There is, however, a dearth of educational audiologists in South Africa at the present time, and their services appear to be concentrated on special needs populations, rather than in schools in general. This situation is expected to change in accordance with changing practices with regard to inclusion.

In conclusion, the roles of the SLT and audiologist in serving learners in schools have evolved over the years as their fields developed and the educational environment and policies changed to include the support of teachers (Wium \& Louw 2013).

\section{Support of teachers}

The importance of consultation and collaboration between professionals in schools with a view to achieving the common goal of improved educational outcomes for learners has resulted in a significant change in the role of the SLT in schools. In addition, the current focus on inclusive education in South Africa has created a dire need for support of both teachers and learners. Collaborative practices between SLTs and teachers are in the development phase in South Africa. Although some teachers may be positive about this, others do not share the same attitude. Wium and Louw (2013) argue that effective collaboration between SLTs and teachers requires both parties to understand their individual roles, and that SLTs take the educational environment into account. Each discipline's knowledge base and approaches, as well as the new 
knowledge, skills and approaches required to work together in supporting learners in South African classrooms, should be taken into account to improve collaboration.

Table 1 provides details of the support given to teachers by SLTs in schools, and illustrates the overlapping roles of teachers and SLTs. The content is based on a description of the roles of teachers as specified by the norms and standards for teachers encapsulated in the Policy on Minimum Requirements for Teacher Education selected from the Higher Education Qualifications Framework (HEQF) (RSA DoE 2011); while the roles of SLTs reflect the minimum competencies required by the HPCSA (2005); the specifications of inclusive education policies (RSA DoE 2001a; 2001b); and a literature review (Ehren \& Ehren 2001; Wium \& Louw 2013). Teacher and SLT collaboration should also accommodate the recent implementation of CAPS (RSA DBE 2010a). The benefits of professional collaboration in attaining positive education outcomes are clear.

\section{Table 1: Support of teachers by SLTs based on professional roles}

\begin{tabular}{|c|c|}
\hline & \\
\hline $\begin{array}{l}\text { Learning mediator: } \\
\text { The educator will } \\
\text { mediate learning in a } \\
\text { manner that is sensitive } \\
\text { to the diverse needs } \\
\text { of learners, including } \\
\text { those with barriers } \\
\text { to learning; construct } \\
\text { learning environments } \\
\text { that are appropriately } \\
\text { contextualised and } \\
\text { inspirational; and } \\
\text { communicate effectively, } \\
\text { showing recognition } \\
\text { of and respect for the } \\
\text { differences of others. } \\
\text { In addition, an educator } \\
\text { will demonstrate sound } \\
\text { knowledge of subject } \\
\text { content and various } \\
\text { principles, strategies and } \\
\text { resources appropriate for } \\
\text { a specific context. }\end{array}$ & $\begin{array}{l}\text { Prevention role: In the prevention of speech, language and hearing } \\
\text { problems, the SLT and audiologists will: } \\
\text { - } \quad \text { Disseminate information to teachers, parents and other } \\
\text { role players; } \\
\text { - Participate in intersectorial planning and transdisciplinary } \\
\text { teamwork of prevention programmes; and } \\
\text { - Support all learners in learning. SLTs play an important role } \\
\text { in supporting the development of language and literacy } \\
\text { of all learners, not only those who have communication } \\
\text { impairments. Many learners in South Africa are at risk of failing } \\
\text { because they are disadvantaged by systemic factors that limit } \\
\text { their opportunities for learning basic language competencies, } \\
\text { regardless of the language they use. } \\
\text { In an inclusive education approach, the SLT and audiologist will } \\
\text { facilitate learning as follows: } \\
\text { - Develop culturally appropriate support programmes, } \\
\text { specifically for learners speaking an additional language that } \\
\text { is not part of the LoLT, with assistance from members of the } \\
\text { cultural group; } \\
\text { - Support learners and teachers in the areas related to literacy } \\
\text { and numeracy based on their knowledge of communication; } \\
\text { - Provide support by creating an optimal learning environment; } \\
\text { - Within an asset-based approach facilitate change by focusing } \\
\text { on learners' strengths and not their weaknesses; and } \\
\text { Engage with teachers, learners and other key role players } \\
\text { (for example, parents, professionals from other disciplines) in } \\
\text { solving communication problems in the learning environment, } \\
\text { rather than making prescriptive decisions. }\end{array}$ \\
\hline
\end{tabular}




\begin{tabular}{|c|c|}
\hline $\begin{array}{r}\text { Profession } \\
\text { teachers (S } \\
20\end{array}$ & $\begin{array}{c}\text { Professional roles of SLTs in schools (based on the minimum } \\
\text { competencies required by the HPCSA for the practice of speech- } \\
\text { language therapy and inclusive education policies) }\end{array}$ \\
\hline $\begin{array}{l}\text { Interpreter and designer } \\
\text { of learning programmes } \\
\text { and materials: The } \\
\text { educator will understand } \\
\text { and interpret provided } \\
\text { learning programmes; } \\
\text { design original learning } \\
\text { programmes; identify } \\
\text { the requirements for } \\
\text { a specific context of } \\
\text { learning; and select and } \\
\text { prepare suitable textual } \\
\text { and visual resources for } \\
\text { learning. The educator } \\
\text { will also select sequence } \\
\text { and pace learning in a } \\
\text { manner sensitive to the } \\
\text { differing needs of the } \\
\text { subject/learning area } \\
\text { and learners. } \\
\text { Teachers have insight } \\
\text { into the context, the } \\
\text { process of teaching and } \\
\text { learning, learners and } \\
\text { the curriculum. }\end{array}$ & $\begin{array}{l}\text { Intervention role: } \\
\text { - } \quad \text { Develop support programmes for learners and parents. } \\
\text { SLTs have specialized skills that support the development } \\
\text { of language learning and literacy, and thereby relate to the } \\
\text { Revised National Curriculum and CAPS. SLTs aim to develop } \\
\text { oral and written language skills, which include listening, } \\
\text { speaking, reading and writing skills. } \\
\text { The mode of service delivery is through whole-class } \\
\text { interventions, small group teaching, and individualised support. } \\
\text { SLTs can contribute to facilitating communication and language } \\
\text { development and developing the underlying knowledge base } \\
\text { for literacy acquisition, for example, phonological awareness, } \\
\text { phonics, and understanding and use of language. Audiologists } \\
\text { focus on the prevention, assessment and management of } \\
\text { hearing problems (including auditory processing problems). } \\
\text { In the foundation phase, the SLT and audiologist will focus } \\
\text { mainly on listening, hearing, language, literacy and numeracy. } \\
\text { In special education, they will be part of a team to plan and } \\
\text { implement individual educational programmes (IEPs) with } \\
\text { stated and measureable outcomes. } \\
\text { Support teachers in inclusive education. Provide educational } \\
\text { opportunities for communication, speech, language, and } \\
\text { related disorders by promoting, planning, executing and } \\
\text { evaluating educational programmes pertaining to the national } \\
\text { curriculum. } \\
\text { Communication } \\
\text { - Language development } \\
\text { Literacy acquisition } \\
\text { Listening and hearing }\end{array}$ \\
\hline
\end{tabular}




\begin{tabular}{|c|c|}
\hline \begin{tabular}{|c|} 
Professional roles of \\
teachers (SchoolNet SA \\
2007) \\
\end{tabular} & $\begin{array}{c}\text { Professional roles of SLTs in schools (based on the minimum } \\
\text { competencies required by the HPCSA for the practice of speech- } \\
\text { language therapy and inclusive education policies) }\end{array}$ \\
\hline $\begin{array}{l}\text { Leader, administrator } \\
\text { and manager: The } \\
\text { educator will make } \\
\text { decisions appropriate } \\
\text { to the level of learning; } \\
\text { manage learning in the } \\
\text { classroom; carry out } \\
\text { classroom administrative } \\
\text { duties efficiently; and } \\
\text { participate in school } \\
\text { decision-making } \\
\text { structures. These } \\
\text { competences will be } \\
\text { performed in ways that } \\
\text { are democratic, support } \\
\text { learners and colleagues, } \\
\text { and demonstrate } \\
\text { responsiveness to } \\
\text { changing circumstances } \\
\text { and needs. }\end{array}$ & $\begin{array}{l}\text { Manager role: SLTs will provide support through interpretation of } \\
\text { the curriculum assessment policy (CAPS) (RSA DBE 2010a). } \\
\text { SLTs have to engage in optimal interdisciplinary collaboration. They } \\
\text { have to plan and work together with teachers, parents and other } \\
\text { disciplines to coordinate goals and objectives. }\end{array}$ \\
\hline $\begin{array}{l}\text { Scholar, researcher and } \\
\text { lifelong learner: The } \\
\text { educator will achieve } \\
\text { ongoing personal, } \\
\text { academic, occupational } \\
\text { and professional } \\
\text { growth through } \\
\text { pursuing reflective } \\
\text { study and research in } \\
\text { his learning area, in } \\
\text { broader professional and } \\
\text { educational matters, and } \\
\text { in other related fields }\end{array}$ & $\begin{array}{l}\text { Manager role: SLTs are a key resource in supporting basic education } \\
\text { priorities emanating from the Action Plan to 2014: Towards the } \\
\text { realisation of Schooling } 2025 \text { (Department of Basic Education, Notice } \\
752 \text { of 2010): } \\
\text { Goal 16: “Improve the professionalism, teaching skills, subject } \\
\text { knowledge and computer literacy of teachers throughout their } \\
\text { entire careers.” Teacher support through in-service continued } \\
\text { professional development (CPD) workshops is important in } \\
\text { developing interventions. Such CPD activities address topics related to } \\
\text { adaptation of the curriculum for learners who experience challenges } \\
\text { to learning, and provision of suitable resources for learning. By } \\
\text { providing workshops for teachers, SLTs and audiologists support } \\
\text { their professional growth in listening, hearing, auditory processing, } \\
\text { language, phonological acquisition and phonic awareness, as well } \\
\text { as literacy. } \\
\text { Researcher role: Evidence-based practice (EBP) will provide } \\
\text { information that could guide decision making in schools and } \\
\text { education management. SLTs and teachers can collaborate and } \\
\text { collate their data on learners' performance to evaluate programmes, } \\
\text { make recommendations, and develop/adjust their interventions. } \\
\text { In terms of research, the SLT will recognise and/or identify regional } \\
\text { and national research needs. It is important that the SLT develop } \\
\text { relevant research themes for action research of educational } \\
\text { practices that will enhance the acquisition of language, literacy and } \\
\text { communication skills. }\end{array}$ \\
\hline
\end{tabular}




\begin{tabular}{|c|c|}
\hline \begin{tabular}{|l} 
Professional roles of \\
teachers (SchoolNet SA \\
2007)
\end{tabular} & $\begin{array}{l}\text { Professional roles of SLTs in schools (based on the minimum } \\
\text { competencies required by the HPCSA for the practice of speech- } \\
\text { language therapy and inclusive education policies) }\end{array}$ \\
\hline $\begin{array}{l}\text { Community, citizenship } \\
\text { and pastoral role: The } \\
\text { educator will practise } \\
\text { and promote a critical, } \\
\text { committed and ethical } \\
\text { attitude towards } \\
\text { developing a sense of } \\
\text { respect and responsibility } \\
\text { towards learners and } \\
\text { their families. Teachers } \\
\text { have to provide support } \\
\text { for and empower the } \\
\text { environment to become } \\
\text { responsive towards } \\
\text { the educational and } \\
\text { other needs of learners. } \\
\text { With reference to their } \\
\text { critical understanding } \\
\text { of community and } \\
\text { environmental } \\
\text { development issues, } \\
\text { teachers have to develop } \\
\text { supportive relationships } \\
\text { with parents and other } \\
\text { key role players in } \\
\text { the community. }\end{array}$ & $\begin{array}{l}\text { Consultative role: SLTs will consult with parents and teachers } \\
\text { as members of a team, and include the community as part of a } \\
\text { wider systems approach. For example, they can present talks } \\
\text { to parent associations and school governing bodies about how } \\
\text { they can support learners and teachers (for example, through } \\
\text { donations of materials and equipment). They can also participate in } \\
\text { fundraising activities to raise funds for the support of learners and } \\
\text { learning programmes. }\end{array}$ \\
\hline
\end{tabular}




\begin{tabular}{|c|c|}
\hline $\begin{array}{l}\text { Professional roles of } \\
\text { teachers (SchoolNet SA } \\
\text { 2007) }\end{array}$ & $\begin{array}{l}\text { Professional roles of SLTs in schools (based on the minimum } \\
\text { competencies required by the HPCSA for the practice of speech- } \\
\text { language therapy and inclusive education policies) }\end{array}$ \\
\hline $\begin{array}{l}\text { Assessor: Considering } \\
\text { that assessment is key } \\
\text { to effective teaching and } \\
\text { learning, teachers must } \\
\text { show an understanding } \\
\text { of the purposes, } \\
\text { methods and effects } \\
\text { of assessment and be } \\
\text { able to provide helpful } \\
\text { feedback to learners. } \\
\text { Teachers must conduct } \\
\text { assessments in } \\
\text { order to modify their } \\
\text { teaching/ learning. } \\
\text { Assessment requires } \\
\text { teachers to design and } \\
\text { manage both formative } \\
\text { and summative } \\
\text { assessments in ways } \\
\text { that are appropriate to } \\
\text { the level and purpose } \\
\text { of learning. } \\
\text { Assessment practices } \\
\text { must meet the } \\
\text { requirements of } \\
\text { accreditation bodies. } \\
\text { It is important that } \\
\text { the educator will } \\
\text { keep detailed and } \\
\text { diagnostic records of } \\
\text { assessment results to } \\
\text { feed into processes for } \\
\text { the improvement of } \\
\text { learning programmes. }\end{array}$ & $\begin{array}{l}\text { Assessment: SLTs/audiologists will contribute to the assessment } \\
\text { of individual learners in the areas of speech, language, listening, } \\
\text { hearing and literacy. In particular, they will (ASHA, 2001): } \\
\text { - } \quad \text { Determine appropriate assessment protocols; } \\
\text { - } \quad \text { Execute a physical examination related to the communication } \\
\text { system and apply appropriate assessment procedures and } \\
\text { relevant tests in order to determine the nature and degree } \\
\text { of problems. Appropriate assessment implies that the } \\
\text { identification of disorders is made in the first language (L1), } \\
\text { combined with assessment in the second language (L2). } \\
\text { Assessment has to be conducted in a manner that is culturally } \\
\text { and linguistically appropriate. Assessment is also ongoing. The } \\
\text { process is, whenever possible, naturalistic and holistic, and } \\
\text { includes the use of non-standardised approaches; } \\
\text { - Compile an accurate assessment report that is descriptive; } \\
\text { - Make appropriate referrals; and } \\
\text { - Conduct consultations and assessment for the purpose of } \\
\text { modifying teaching and/or learning. } \\
\text { It is necessary to distinguish between learners who are not } \\
\text { appropriately proficient in L2 despite full language potential, } \\
\text { and learners who are not fully proficient in L1 and L2 due to a } \\
\text { communication disorder. In the former case, SLTs should play a } \\
\text { consultative and preventative role by providing information on } \\
\text { programming strategies and environments that promote both } \\
\text { the mastery of L2 and the retention of L1. The provision of clinical } \\
\text { and consultative services would only be appropriate if a specific } \\
\text { language impairment or language delay is identified. }\end{array}$ \\
\hline
\end{tabular}




\begin{tabular}{|c|c|}
\hline $\begin{array}{l}\text { Professional roles of } \\
\text { teachers (SchoolNet SA } \\
\text { 2007) }\end{array}$ & $\begin{array}{l}\text { Professional roles of SLTs in schools (based on the minimum } \\
\text { competencies required by the HPCSA for the practice of speech- } \\
\text { language therapy and inclusive education policies) }\end{array}$ \\
\hline $\begin{array}{l}\text { Learning area/ } \\
\text { subject/discipline/ } \\
\text { phase specialist: } \\
\text { Teachers have the } \\
\text { mandate to teach } \\
\text { learners to speak, } \\
\text { spell, read, write and } \\
\text { problem solve. }\end{array}$ & 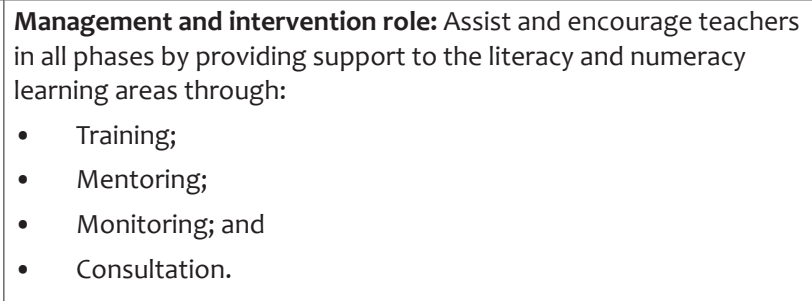 \\
\hline $\begin{array}{l}\text { The educator will be } \\
\text { well grounded in the } \\
\text { knowledge, skills, values, } \\
\text { principles, methods and } \\
\text { procedures relevant to } \\
\text { the discipline, subject, } \\
\text { learning area, phase of } \\
\text { study, or professional or } \\
\text { occupational practice. }\end{array}$ & \\
\hline $\begin{array}{l}\text { The educator will } \\
\text { know about different } \\
\text { approaches to teaching } \\
\text { and learning, and } \\
\text { how these may be } \\
\text { used in ways that are } \\
\text { appropriate to the } \\
\text { learners and the context. }\end{array}$ & \\
\hline $\begin{array}{l}\text { The educator will } \\
\text { have a well-developed } \\
\text { understanding of the } \\
\text { knowledge appropriate } \\
\text { to the specialism. }\end{array}$ & \\
\hline
\end{tabular}

\section{The curriculum and assessment policy statement (CAPS)}

\section{Defining the concept}

The National Curriculum Statement (NCS) (Motshekga 2010; RSA DoE 2002) represents a policy statement for learning and teaching in South African schools and, since 2011, includes the CAPS (RSA DBE 2010a) provisions for each approved school subject in each grade and in different languages, especially for foundation phase education. CAPS focuses particularly on literacy and numeracy, as these two subject areas form the basis for all learning. However, the re-training of teachers (Motshekga 2011) and adequate teacher support is key to the successful implementation of this policy document. In literacy in the foundation phase, the focus is on the learning areas of listening and speaking, reading and phonics, handwriting and writing, and language structures and use (conventions) (RSA DBE 2012). SLTs are ideally suited to support 
teachers in the implementation of these aspects of the curriculum, especially in the foundation phase (Kathard et al 2011). Figure 1 illustrates the role of the SLT in CAPS.

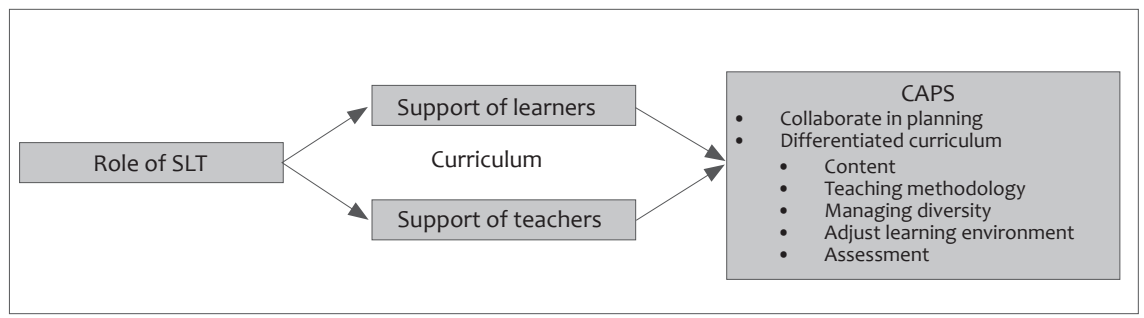

\section{Figure 1: The collaborative role of the SLT within the CAPS framework}

With reference to Figure 1, it is proposed that teachers could collaborate with SLTs in planning their lessons, in an effort to accommodate individual learner needs. SLTs can support teachers in multilevel teaching through a process of team teaching or co-teaching, where the teacher can continue to work with the main group while the SLT focuses on individual learners or small groups (Paul \& Norbury 2012; Wilkinson \& Culatta 2013). This may require that teachers and SLTs function as a team and constantly re-evaluate methods of teaching and assessment, and, where necessary, adapt their approaches, methodologies and strategies (RSA DBE 2010a).

\section{Importance of the curriculum policy document}

One of the general aims of CAPS (RSA DBE 2010a) is inclusivity, which necessitates differentiation in the curriculum. Differentiation is a key strategy for extending and varying aspects of the curriculum (for example, content and teaching) in response to diversity, as it takes into account differences in learners' ability levels, interests and background, etcetera. The curriculum policy requires adapting teaching and assessment methods and the learning environment, which would include classroom management (ibid). Differentiation of content requires that learning material be adapted and presented at varying degrees of complexity. Such differentiation is required to provide access to learning and to ensure that all learners experience success. The latter is of particular importance to learners who face barriers to learning. The consequences of academic failure often result in low self-esteem, social maladjustment, and ultimately the inability to sustain themselves financially (Mamum 2000). Academic failure should be avoided at all cost, and every effort must be made to support learning in order to help learners succeed.

In view of the close relationship between language, literacy and learning (Wium, Louw \& Eloff 2011), it is imperative that teachers and SLTs work as a team in supporting learners. As team members, they must have equal respect for each other and show an ability to work towards similar outcomes (O'Toole \& Kirkpatrick 2007). Support and collaboration in schools and classrooms are essential for creating a supportive environment. Friend and Cook (2003:5) describe collaboration as a "style of direct interaction between at least two equal parties voluntarily engaged 
in shared decision making as they work towards a common goal". Lavonen (2013) holds that collaboration between professionals in a school is a keystone of the successful Finnish education system.

The collaborative model of support encourages team members to share their disciplinary knowledge with each other (Engelbrecht 2001). SLTs and teachers should share the responsibility of facilitating learning. Staskowski (2003:201) explains that successful collaboration among literacy teams (including SLTs) involves "frequent and meaningful communication and understanding of one another's expertise".

\section{Benefits and difficulties of collaboration}

The benefits of collaboration have been noted to include improving learners' communication skills and giving them better access to the national curriculum, because it helps teachers to develop a better understanding of the impact of communication problems on a child and of how to address such difficulties, which in turn results in the learner developing greater self-esteem. Apart from benefitting learners, such collaboration also benefits staff (Baxter, Brookes, Bianchi et al 2009), as they feel more supported. The positive outcomes experienced by staff are linked to joint problem solving and professional development.

However, several factors adversely impact on effective collaboration. At present, there are limited positions for SLTs in the public sector, and only a few learners receive support from private practitioners. The issue of low staffing requires a collaborative approach and inter-disciplinary teamwork. Mutual trust and respect are crucial elements for an effective joint working relationship (Baxter et al 2009). It is possible that teachers regard SLTs as 'outsiders', which creates a social barrier that could negatively impact on the development of mutual trust and respect. Teachers are required to implement the curriculum, whereas SLTs who work on a private basis may have more autonomy in their approach and implementation strategies. Other difficulties encountered in efforts to collaborate are insufficient time available for quality liaison, and a school culture that does not value SLT input (Law, Lindsay, Peacey et al 2002). Teachers may also feel that they do not get sufficient support from SLTs in terms of training to meet the needs of learners with communication difficulties (Baxter et al 2009).

In spite of such barriers to collaboration, team work supports inclusivity, and serious future efforts are required to achieve the ultimate aim of supporting all learners to attain optimal educational outcomes. Collaboration and teacher support is especially relevant within the inclusive education model mandated by White Paper 6 (RSA DoE 2001b).

\section{Educational inclusion}

The South African Constitution of 1996 paved the way for a just and equitable society, an ideal that was reinforced by several policies for educational reform (RSA DoE 1995; 1996; 2001b). Education White Paper 6 on Special Needs Education: 
Building an Inclusive Education and Training System (RSA DoE 2001b) acknowledges and respects that all learners can learn, and is therefore based on a philosophy of inclusivity. All learners can learn, provided that the curriculum and assessment practices are differentiated. According to the Guidelines for responding to learner diversity in the classroom (RSA DBE 2012), inclusivity is one of the general aims of the South African school curriculum.

Despite the various policy documents mentioned here, inclusive education has not yet been fully accepted or implemented in South Africa. The concept requires a notable shift away from referring to a child as having 'special needs', which reflects a child deficit/medical deficit model, to referring to 'barriers to learning and development', which reflects a a systems change/social rights model. The premise of inclusive education is that learner diversity exists in any classroom, regardless of whether that classroom is in an ordinary school or a special one. 'Barriers to learning' refer to difficulties arising within the education system as a whole, a specific learning site, and/or the learner, and which prevent access to learning and development for some learners. According to CAPS (RSA DBE 2010a), the key to managing inclusivity is ensuring that obstructive practices in the system are identified and addressed by all the relevant support structures within the school community. Obstructive and disabling phenomena, structures and practices are:

- Systemic: For example, overcrowded classrooms, school buildings that are inaccessible to the physically impaired, lack of basic and appropriate learning materials, exclusionary policies and practices, etcetera.

- Societal: For example, poverty, lack of safety and security, children affected by HIV/AIDS, child-headed households, children living in the streets, children in conflict with the law, etcetera.

- Pedagogical: For example, inappropriate teaching methods and learning and teacher support material, unqualified or underqualified teachers, inappropriate assessment procedures, lack of support for teachers, etcetera.

- Intrinsic: For example, barriers faced by learners with neurological, physical, sensory and cognitive impairments or psychosocial and emotional difficulties, etcetera.

Some of these obstacles require specialised intervention skills, which can be provided either in specialised settings such as special schools, or in mainstream schools with specialist assistance and collaboration. Table 2 shows the various barriers to learning, with suggestions of how SLTs can support teachers and learners in the classroom to address these barriers. 
Table 2: Collaborative support to teachers by SLTs within inclusive education

\begin{tabular}{|c|c|}
\hline $\begin{array}{l}\text { Type of barrier to learning (RSA } \\
\text { DBE 2012) }\end{array}$ & Collaborative support provided by SLTs \\
\hline $\begin{array}{l}\text { Socio-economic deprivation (poverty, } \\
\text { lack of access to basic services, } \\
\text { inaccessible environments and } \\
\text { unsafe buildings) }\end{array}$ & $\begin{array}{l}\text { Provide support to teachers: consultations to } \\
\text { make classrooms more accessible for learners who } \\
\text { experience barriers (for example, creating an optimal } \\
\text { listening and learning environment for learners with } \\
\text { hearing impairment, AAC users, etcetera) }\end{array}$ \\
\hline $\begin{array}{l}\text { Barriers resulting from } \\
\text { impairments (physical, cognitive, } \\
\text { sensory, developmental and } \\
\text { learning impairments) }\end{array}$ & $\begin{array}{l}\text { Provide support to teachers and learners: curriculum } \\
\text { adaptation and assessment }\end{array}$ \\
\hline $\begin{array}{l}\text { Opportunity barriers caused by } \\
\text { negative attitudes and stereotyping }\end{array}$ & $\begin{array}{l}\text { SLTs can provide information on disability and } \\
\text { barriers to learning to role players and learners in } \\
\text { the classroom. Attitudes can be related to the notion } \\
\text { that all learners need to be supported. Landsberg } \\
\text { et al (2007:20) relate inclusion to beliefs, values and } \\
\text { attitudes about diversity, change, collaboration and } \\
\text { learning. Negative attitudes, assumptions and beliefs } \\
\text { must be addressed directly, as these can be directed } \\
\text { into actions and teaching practices. }\end{array}$ \\
\hline Inflexible curriculum & $\begin{array}{l}\text { Provide support to teachers and learners: curriculum } \\
\text { and assessment adaptations }\end{array}$ \\
\hline $\begin{array}{l}\text { Inappropriate language, or language } \\
\text { of learning and teaching (LoLT) and } \\
\text { language of communication }\end{array}$ & $\begin{array}{l}\text { Provide individual learner support as well as whole- } \\
\text { class support. } \\
\text { Provide teacher support with regard to teaching } \\
\text { practices and strategies to accommodate learners } \\
\text { who are learning in a different language than their } \\
\text { home language (L1). }\end{array}$ \\
\hline $\begin{array}{l}\text { Lack of or inappropriate } \\
\text { support services }\end{array}$ & $\begin{array}{l}\text { Collaborate with district-based support teams and } \\
\text { other disciplines }\end{array}$ \\
\hline $\begin{array}{l}\text { Policies and legislation that } \\
\text { are inadequate }\end{array}$ & $\begin{array}{l}\text { SLT in an advocacy role: provide information on } \\
\text { inclusion to broader community }\end{array}$ \\
\hline $\begin{array}{l}\text { Lack of parental support } \\
\text { and involvement }\end{array}$ & $\begin{array}{l}\text { Continual contact with primary caregivers through, for } \\
\text { example, notebooks }\end{array}$ \\
\hline
\end{tabular}

It is evident from Table 2 that SLTs can provide support on multiple levels to both learners and teachers in order to address individual learners' needs and ensure positive educational outcomes for learners challenged by barriers to learning.

\section{Collaboration across the curriculum}

The focus of teachers is mainly on the academic progress of learners, as their mandate is to facilitate learning in all learners. However, they are faced with various 
challenges, which are intrinsic and/or extrinsic to either the learners, the curriculum, the context and the classroom, and can therefore benefit from the support of SLTs. In terms of the school curriculum, teachers are required to differentiate the curriculum and adjust their teaching and assessment practices to suit learners' needs. However, recent changes in education policy with regard to the curriculum may be experienced as challenging, which is why the DBE (2012) recommend that teachers become part of collaborative support networks. SLTs working in school contexts are equipped to support teachers, and should become part of such collaborative networks so as to support teachers in curriculum differentiation, creating facilitative learning environments, and addressing the needs of all learners. Such collaboration also facilitates professional growth (ibid).

The collaborative model of support focuses on the identification and management of barriers to learning at the learner, teacher, curriculum and institutional levels (RSA DoE 2001b). Such a collaborative approach requires a range of service delivery models, depending on the context and the needs of the learners and teachers (Cirrin, Schooling, Nelson et al 2010; Wium \& Louw 2013).

The traditional 'pull-out' model of support (Brandel \& Loeb 2011) provides intervention to learners outside the classroom on an individual basis. The provision of individual support is determined by the nature and severity of some disabilities, or the needs and characteristics of the learner (ibid; Cirrin et al 2010). Examples of applying the 'pull-out' model would be the provision of SLT services to children with, for example, swallowing disorders (dysphagia). In the consultative model (Law et al 2002), the SLT, as expert in communication and language, consults with teachers, which is an indirect intervention approach. Although this model is more cost-effective than the collaborative model (Brandel \& Loeb 2011), it relies on liaison, which can potentially create an imbalance in the power relationship between professionals. Wright and Kersner (2001) emphasize the need for teachers and SLTs to 'give and take' knowledge, which implies a two-way flow of information. Each professional should be regarded as an equal partner who shares her knowledge and skills to obtain maximum benefit from the intervention.

Learners need support in order to learn and develop age-appropriate listening and language skills, which in turn are required for literacy development. Communication and learning difficulties also need to be prevented. In an inclusive approach, prevention requires SLTs to support all learners through whole-class teaching in the literacy curriculum, but also to focus on individual learners within the classroom. Teachers may therefore want to collaborate with the SLT in planning and implementing inclusive education and monitoring learners' progress.

Teachers remain the key players in the successful implementation of inclusive education, which means that their knowledge and skills need to be continually refreshed and developed. CAPS requires SLTs to support teachers through training, mentoring, monitoring and consultation. SLTs are in a position to provide this support in the form of staff development and in-service training, where the focus is on a conceptual framework and language, as well as instructional and technical skills 
to accommodate the diverse needs of learners (Wium et al 2011). In order to ensure optimal teaching practices, such support should be provided within the school context and focus on the specific concerns of teachers. Such teacher support makes teachers feel valued and motivated, renews their enthusiasm, and prevents burnout (Earley \& Bubb 2004).

As both disciplines focus on language, literacy and learning, it is imperative that teachers and SLTs work as a team in supporting learners in the acquisition of literacy. Collaboration requires clear objectives for each discipline (Hartas 2004). The exact roles and expectations of each profession should be known, and a system should be in place that emphasizes joint effort and working together. Each partner should share in the responsibilities and decision making, and exchange ideas and resources. In addition, there should be shared accountability for the outcomes of their collaboration. SLTs and teachers should understand that they are much more effective as a team than working separately. It is important that they value their interdependence (Wilkinson \& Culatta 2013).

SLTs can support teachers with a response to intervention/instruction (RTI) approach (Wilkinson \& Culatta 2013), which consists of a three-tier system of support to fit individual learners' needs, based on their assessment results. Learners experiencing barriers and who may be struggling are provided with interventions at increasing levels of intensity to fast-track learning and enable them to keep up with their peers. Interventions are based on the individual response to the intervention or instruction.

In the foundation phase, the literacy curriculum requires a supportive language learning environment, and the three-tiered RTI approach is best suited for this (Roth \& Troia 2009). In such an approach, it may be sufficient for the teacher to provide strong classroom instruction (Tier 1 instruction) that the majority (usually $80 \%$ of learners) may benefit from (ibid), but there may be those (15\%) who require more intense instruction (Tier 2 instruction). In such instances, the teacher may want to group the learners and have the SLT support some groups through co-teaching (Paul \& Norbury 2012). Should there be individual learners who experience barriers to learning and may require even more intense supplemental instruction (Tier 3), they may then be referred to the SLT for specialised one-on-one instruction (Wilkinson \& Culatta 2013). Such interventions are based on effective collaboration between SLTs and teachers (Wium, Louw \& Eloff 2010).

Based on assessment outcomes, the teacher and SLT may work as a team to select specific tasks and activities aimed at facilitating various levels of advancement in the cognitive domain (for example, knowledge, comprehension, application, analysis, synthesis and evaluation) (Anderson \& Krathwohl 2001) for various learners. The SLT can prepare learners for such tasks by explaining and demonstrating the meaning of the words in advance.

Individual education plans (IEPs) (Mauro 2014) have not commonly been used in South African schools to date. For learners with impairments, IEPs are tailored to the individual learner's needs, as it specifies relevant academic goals and how to achieve them, as well as transition plans. SLTs and teachers can collaborate on developing IEPs for learners who experience specific barriers to learning. 
Effective collaboration is not necessarily suitable for all learners. McCartney, Ellis \& Boyle (2009) argue that learners with specific language impairments may benefit more from individualised intervention provided by SLTs than from teachers supporting them in the classroom, as the classroom environment may not provide an optimal languagelearning environment for learners with severe and persistent language impairment.

\section{Conclusion}

The Department of Basic Education has identified learner performance as one of its ongoing key challenges. Critical actions that have been identified and which need to be implemented throughout the entire system include the strengthening of monitoring, evaluation and support, especially for teachers (Motshekga 2013). The evolving role of SLTs and the educational changes brought about by White Paper 6 (RSA DoE 2001b) and CAPS (RSA DBE 2010a) have set the stage for a new approach to collaboration between teachers and SLTs. Collaboration has been identified as a powerful tool to improve outcomes for all learners.

Despite the emphasis on collaborative practices in schools, interprofessional collaboration remains challenging. An urgent need exists for action to be taken on multiple levels in order to address this situation. The argument in this paper has been that collaboration can support children and their teachers. It requires a systemic change, whereby 'outsider' specialists are welcomed into schools and into classrooms as 'insider' professionals.

\section{References}

Anderson, L. \& Krathwohl, D.A. 2001. A taxonomy for learning, teaching and assessing: a revision of Bloom's taxonomy of education objectives. New York: Longman.

ASHA (American Speech-Language-Hearing Association). 2001. Roles and responsibilities of speech-language pathologists with respect to reading and writing in children and adolescents. ASHA Guidelines. Rockville, MD: ASHA.

ASHA (American Speech-Language-Hearing Association). 2010. Roles and responsibilities of speech-language pathologists in schools. Practice Policy. Professional Issues Statement. Rockville, MD: ASHA.

Baxter, S., Brookes, C., Bianchi, K., Rashid, K. \& Hay, F. 2009. Speech and language therapists and teachers working together: Exploring the issues. Child Language Teaching and Therapy, 25:215-18. DOI: 10.1177/0265659009102984.

Brandel, J. \& Loeb, D.F. 2011. Program Intensity and Service Delivery Models in the Schools: SLP Survey Results. Language, Speech, and Hearing Services in Schools, 42:461-90.

Cirrin, F.M., Schooling, T.L., Nelson, N.W., Diehl, S.F., Flynn, P.F., Staskowski, M., Torrey, T.Z. \& Adamczyk, D.F. 2010. Evidence-Based Systematic Review: Effects of Different Service Delivery Models on Communication Outcomes for Elementary School-Age Children. Language, Speech, and Hearing Services in Schools, 41:233-64. DOI: 10.1044/0161-1461(2009/08-0128). 
EAA (Educational Audiology Association). 2009. Recommended professional practices for educational audiology Retrieved from http://c.ymcdn.com/sites/www.edaud. org/resource/resmgr/imported/Professional\%20Practices_pos09_REVISED.pdf (accessed 10 August 2014).

Earley, P. \& Bubb, S. 2004. Leading and managing continuing professional development: developing people, developing schools. Thousand Oaks, CA: Sage.

Ehren, B.J. \& Ehren, T.C. 2001. New or expanded literacy roles for speech-language pathologists: Making it happen in schools. Seminars in Speech and Language, 22(3):233-41.

Engelbrecht, P. 2001. Changing roles for education support professionals. In: P. Engelbrecht \& L. Green (Eds). Promoting learner development: Preventing and working with barriers to learning. Pretoria: Van Schaik. 17-29.

Friend, M. \& Cook, L. 2003. Interactions: collaboration skills for school professionals. Boston, MA: Allyn \& Bacon.

Hartas, D. 2004. Teacher and speech-language therapist collaboration: being equal and achieving a common goal? Child Language Teaching and Therapy, 20:33-53.

HPCSA (Health Professions Council of South Africa). 2005. Exit level outcomes. Pretoria: HPCSA.

Jordaan, H. 2011. Language teaching is no panacea: a theoretical perspective and critical evaluation of language in education within the South African context. South African Journal of Communication Disorders, 58:79-85.

Kathard, H., Jordaan, H., Moonsamy, S., Wium, A.M., Du Plessis, S., Ramma, L., Pottas, L., Banu Khan, N. \& Pascoe, M. 2011. How can Speech Language Therapists and Audiologists enhance language and literacy outcomes in South Africa? (And why we urgently need to). South African Journal of Communication Disorders, Special Edition, 53:1-8.

Landsberg, E., Kruger, D. \& Nel, N. 2007. Addressing barriers to learning: A South African perspective. Pretoria: Van Schaik Publishers.

Lavonen, J. 2013. Teacher Education in Finland: The role of training schools affiliated to universities. Public lecture at the University of Johannesburg, Auckland Park, South Africa, 20 November.

Law, J., Lindsay, G., Peacey, N., Gascoigne, M., Soloff, N., Radford, J. \& Band, S. 2002. Consultation as a model for providing speech and language therapy in schools: a panacea or one step too far? Child Language Teaching and Therapy, 18:145-162.

Mamum, J.I. 2000. Coalition for Inclusive Education in Bangladesh. International Special Education Congress, University of Manchester. Retrieved from http://www. isec20000.org.uk.abstracts/papers-m/mamun-1 htm (accessed 5 March 2005).

Mauro, T. 2014. What is an IEP? Retrieved from http://specialchildren.about.com/od/ specialeducation/f/iepfaq01.htm (accessed 18 August 2014). 
McCartney, E., Ellis, S. \& Boyle, J. 2009. The mainstream primary classroom as a language-learning environment for children with severe and persistent language impairment - implications of recent language intervention research. Journal of Research in Special Education Needs, 9(2):80-90.

Motshekga, A. 2010. Statement by the Minister of Basic Education, Mrs Angie Motshekga, MP, on the progress of the review of the National Curriculum Statement. Pretoria: Department of Basic Education. Retrieved from http://www.education.gov.za (accessed 17 August 2011).

Motshekga, A. 2011. Statement on the release of the Annual National Assessment results for 2011. Retrieved from http://www.education.gov.za/Newsroom/Speeches/tabid/298/ Default.aspx (accessed 17 August 2011).

Motshekga, A. 2013. Statement on the Release of the Annual National Assessments Results for 2013. Newsroom Speeches, 5 December 2013. Pretoria: Department of Basic Education.

Naicker, S.M. 2000. From apartheid education to inclusive education: the challenges of transformation. In: International Education Summit for a Democratic Society, 26-28 June 2000, Detroit, M, Wayne State University. 1-13.

O'Toole, C. \& Kirkpatrick, V. 2007. Building collaboration between professionals in health and education through interdisciplinary training. Child Language Teaching and Therapy, 23(3):325-352.

Owens, R.E. 2002. Language development: An Introduction. Boston, MA: Allyn \& Bacon.

Paul, R. \& Norbury, C. 2012. Language disorders from infancy through adolescence: listening, speaking, reading, writing and communicating. New York: Elsevier Health Sciences.

Ratshitanga, M. 2007. Our present is indeed connected to our past. Pretoria News, 20 March:15.

Roth, F.P. \& Troia, G.A. 2009. Applications of responsiveness to intervention and the speech-language pathologist in elementary school settings. Seminars in Speech and Language, 30(2):75-89. DOI: 10.1055/s-0029-1215716.

RSA DBE (Republic of South Africa. Department of Basic Education). 2010a. Curriculum Assessment Policy Statement (CAPS). Pretoria: Government Printers.

RSA DBE (Republic of South Africa. Department of Basic Education). 2010b. Improving the quality of learning and teaching: Planning for 2010 and beyond. Curriculum News, January 2010.

RSA DBE (Republic of South Africa. Department of Basic Education). 2012. Guidelines for responding to learner diversity in the classroom. Pretoria: Department of Basic Education. Retrieved from www.thutong.doe.gov.za/InclusiveEducation (accessed 1 August 2014 2014).

RSADoE(Republic of SouthAfrica. Department of Education).1995. WhitePaperonEducation and Training in a Democratic South Africa: First Steps to Develop a New System. Retrieved from http://webcache.googleusercontent.com/search?q=cache:mH2Jlb7DIJoJ:www. education.gov.za/LinkClick.aspx\%3Ffileticket\%3D855fT9w3A2U\%253D\%26tabid\%3D191 \%26mid\%3D484+\&cd=1\&hl=en\&ct=clnk\&gl=za (accessed 3 August 2015). 
RSA DoE (Republic of South Africa. Department of Education). 1996. The South African Schools Act 1996. Pretoria: Actsonline. Retrieved from http://www.acts.co.za/ed_ sasa/index.htm (accessed 24 October 2011).

RSA DoE (Republic of South Africa. Department of Education). 1997. Language in education policy. South Africa. Retrieved from http://www.education.gov.za/ LinkClick.aspx?fileticket=XpJ7gz4rPTo\%3D (accessed 3 August 2015).

RSA DoE (Republic of South Africa. Department of Education). 2001a. Education White Paper 5 on Early Childhood Education: Meeting the Challenge of Early Childhood Development in South Africa. Pretoria: Department of Education.

RSA DoE (Republic of South Africa. Department of Education). 2001b. Education White Paper 6 on Special Needs Education: Building an Inclusive Education and Training System. Pretoria: Department of Education. Retrieved from http://www.polity. org.za/govdocs/white_papers/educ6.html (accessed 16 September 2011).

RSA DoE (Republic of South Africa. Department of Education). 2002. Revised National Curriculum Statement for Schools: Grades R-9. Pretoria: Department of Education.

RSA DoE (Republic of South Africa. Department of Education). 2008. National strategy on screening, identification, assessment and support. Pretoria: Department of Education.

RSA DoE (Republic of South Africa. Department of Education). 2011. Policy on Minimum Requirements for Teacher Education. Retrieved from www.gov.za/sites/www.gov. za/files/34467_gon583.pdf (accessed 5 June 2015).

SchoolNet SA. 2007. The seven roles of educators. Retrieved from http://ace.schoolnet. org.za/cd/ukzncoreza/documents/coreza.7roles.htm (accessed 18 October 2011).

Staskowski, M. 2003. Reaching for the stars: SLPs shine on literacy teams. Seminars in Speech and Language, 24(3):199-213.

Van Kleeck, A., Gillam, R. \& McFadden, T.U. 1998. A study of classroom-based phonological awareness training for preschoolers with speech and/or language disorders. American Journal of Speech-Language Pathology, 7(3):65-76.

Wilkinson, J. \& Culatta, B. 2013. Learning and Improving Together: Collaborative Professional Development. In: B. Culatta, K.M. Hall-Kenyon \& S. Black (Eds). Systematic and engaging early literacy: Instruction and Intervention. San Diego, CA: Plural Publishing. Retrieved from http://passthrough.fw-notify. net/download/870855/http://education.byu.edu/sites/default/departments/ projectseel/documents/Teaching_Expository_Comprehension_Skills_in_Early_ Childhood_Classrooms.pdf (accessed 1 August 2015).

Wium, A.M. \& Louw, B. 2013. Revisiting the roles and responsibilities of SLTs in South African schools. South African Journal of Communication Disorders, 60:31-37. DOI: 10.7196/SAJCD.247.

Wium, A.M., Louw, B. \& Eloff, I. 2010. Speech-language therapists supporting foundation phase teachers with literacy and numeracy in a rural and township context. South African Journal of Communication Disorders, 57(1):14-22. 
Wium, A.M., Louw, B. \& Eloff, I. 2011. Evaluation of a programme to support foundation phase educators to facilitate literacy. South African Journal of Communication Disorders, 58(2):72-78.

Wright, J. \& Kersner, M. 2001. Supporting children with communication problems: sharing the workload. London: David Fulton.

Yoncheva, Y., Wise, J. \& McCandliss, B. 2015. Hemispheric specialization for visual words is shaped by attention to sublexical units during initial learning. Brain and Language, 145-146(June-July):23-33. DOI: 0093-934X, dx.doi.org/10.1016/j. bandl.2015.04.001. 